\title{
Through troubled times: reflections on Ron Johnston's Geography and Geographers: Anglo-American Human Geography since 1945 (1979) and Peter Taylor's Political Geography: World Economy, Nation-State and Locality (1985)
}

\author{
James D. Sidaway $\cdot$ Michiel van Meeteren $\cdot$ Colin Flint
}

Published online: 7 May 2020

(C) Springer Nature B.V. 2020

\begin{abstract}
This article introduces the commentaries and rejoinders collated in this collection about the longevity and contemporary relevance of two landmark textbooks in human geography: Geography and Geographers and Political Geography. After putting the emergence of both books in their historical context we discuss their meandering route through the development of geographical thought since. Reflecting on the commentaries and the rejoinders, the impossibility of writing a contemporary textbook with even a veneer of comprehensiveness takes centre stage. Resultantly we debate the future of the geography textbook and what strategies can be surmised to bridge the increasingly self-referential siloes in geographical thought.
\end{abstract}

This article has been republished with minor changes. These changes do not impact the academic content of the article.

J. D. Sidaway $(\bowtie)$

Department of Geography, National University of

Singapore, Kent Ridge, Singapore 117570, Singapore

e-mail: geojds@nus.edu.sg

M. van Meeteren

Geography and Environment, School of Social Sciences and Humanities, Loughborough University, Epinal Way, Loughborough LE11 3TU, UK

e-mail: m.van-meeteren@lboro.ac.uk

C. Flint

Department of Political Science, Utah State University, Logan, UT 84322-0700, USA

e-mail: colin.flint@usu.edu
First appearing within 6 years of each other, both Geography and Geographers: Anglo-American Human Geography since 1945 (1979) and Political Geography: World-Economy, Nation-State and Locality (1985) have each since gained a co-author and each are now in a seventh edition. The trajectories of both books trace, reflect and sometimes collide with the changing tides of the social world and the way that world is represented in geographical scholarship. Making these traces, reflections and collusions visible says much more than an assessment of the continued value of two well-established textbooks. It likely reveals features of the wider state of contemporary geography. Both books first appeared when there were relatively few competing titles, so they quickly found niches. There have since been many more alternative textbooks, edited collections, dictionaries, enclyclopedia's that guide readers to the domains of political geography and the history of geography. In subsequent editions, Political Geography and Geography and Geographers came to represent one possible flavour among peers.

The essays that follow arise from a panel held on 29 August 2019, at the Annual Conference of the Royal Geographical Society (with the Institute of British Geographers) in London. We took advantage of the fact that both Ron Johnston and Peter Taylor were able to attend the conference to stage a discussion about the trajectory (past, present and future) of their two landmark textbooks. The panellists and the essays they wrote embody a range of backgrounds, career 
stages, and locations, yielding diversity in 'authorial voices' often lacking in accounts of the history of geography (Keighren 2020, p. 166). The panellists were encouraged to reflect on the ways in which the textbooks inspired them or how they found use for them, but also reflect on why they would not 'feel at home' in the textbooks. Which expectations do the books fail to meet despite an almost 4 decades of careful curation? The panellists recognize the achievements of each book, but signal original and enduring limits and lacunae. In inviting Peter and Ron to respond, we also asked them both to illuminate the original contexts to each book. How did they come to be written in the first place? What has surprised them about their subsequent reception and longevity?

If there is one takeaway from the last half century of historiographical reflection on science and intellectual histories, it is that all scholarship is a product of its time and place. Therefore, the choices in writing and the debates in geography, what is considered relevant and noteworthy at a particular moment, reflect the wider social environment at the time of writing (Van Meeteren and Sidaway 2020). Although acknowledging situatedness is key to decentre and provincialize any attempt to assemble bits of information into a corpus of knowledge (Leitner and Sheppard 2016), we nevertheless note that themes, foci and contexts do tend to resurface if enough time passes.

Whilst we assembled and edited these written versions of the original exchanges in London, the UK has seen a general election and left the EU. As we finalized the set and it goes to press, there was a sense of return to the political moment,- - after 1979, through the 1980s — of Tory hegemony, when both books appeared in their first editions. The terrain of resistance has shifted and a new generation now leads the Conservative party. Nonetheless, as Watkins (2020, p. 5) noted in an essay in the January-February 2020 issue of New Left Review:

As the United Kingdom exits the EU, the political scene has all the trappings of a restoration. The Tories are back in office with their largest majority since the 1980 s, thanks to the long-ignored northern working class. The UK is resuming its offshore relationship to the project of European integration it had in the 1960s. The Prime Minister is a reversion to type: Old
Etonian...even if his family background is more cosmopolitan-bohemian than landed-capitalist.

Watkins goes on to note that, "the nature of Johnson's ascendancy is best grasped through the multiple crises-economic, social, regional, national, European-to which it presents a solution" (p. 5). The struggles over alternative paths to settle the UK's complex crisis, compounded by a series of unresolved national questions and uneven development were condensed by Brexit and the Tory majority that cemented it. But these have been decades in the making and belong to the long-standing questions about post-imperial Britain's decline and destiny. Similar issues were no less evident when both books appeared.

Although Geography and Geographers and Political Geography have distinctive topical foci, we propose that both first editions might be placed in what Ferguson et al. (2011) and Villaume et al. (2006) term the 'Long 1970s', a period that saw both revolutions and counterrevolutions, crisis, technosocial shifts and the re-animation of neo-liberalism that has roots back to the 1920s (Slobodian 2018). Environmentalism too matured in the 1970s. Carson's (1962) Silent Spring had appeared in the early 1960s, serialised in the New Yorker in the summer of 1962, then as a book in September of that year. Arguably however, it was the long 1970s that saw demands for environmental protection and action over pollution, conservation and sustainability mature into wider debates, fermenting lobby and legislation. In turn, other social movements that gathered momentum in the late 1960 s, notably second wave feminism and gay liberation matured and broadened in the long 1970s. Although the 1960s had seen heightened struggle and achievements, notably the African-American led civil rights movement, Black and other ethnic minority struggles for rights and resistance to racism acquired renewed visibility in the long 1970s. The mid-1960s had seen the landmarks in the civil rights struggle and the ending of nationally specified immigration Quotas (that had privileged migration from Europe) in the USA. However it was in the 1970s that, both the USA and Britain became more consciously 'multicultural' (though references to multiculturalism only became more widespread as a supplement to discourses around 'race' in the 1980s). 
Intellectual currents of the 1970s too, both within and beyond geography, are part of the backdrop to both books. For Geography and Geographers, this was the series of paradigmatic revolutions. Once a quantitative revolution was declared in the 1960 s, other selfdeclared paradigm shifts followed yielding a complex landscape in the 1970s, in need of a guidebook. For Political Geography, the flourishing of world-systems analysis offered inspiration. According to Lee (2011, p. 27):

World-systems analysis emerged in the 1970s, closely related to the medium-term decline of the world economic expansion that had been operative over the preceeding quarter century and the end of the period of hegemony in the interstate system over the same period, which had been marked by the post-Second World War dominance of the United States.

Of course, when considering the wider historicalgeographical contexts in which both books first appeared, we acknowledge the difficulty of such a task, manifested in the ways that historiographical categories must always be subject to ongoing debate. Reflecting on the British case, for example Hilton et al. (2017, p. 150) note that:

The 1970s is better seen not as a decade of organic 'crisis' but as one where various evolving problems and the variety of solutions put forward to remedy them created a 'marketplace of ideas': a difficult decade, but one ripe with potential. Thatcherism was not simply a response to a particular crisis, but constructed the first accounts of that 'crisis'.

However, for Caryl (2013, p. xiii), "It was 1979 that the twin forces of market and religion, discounted for so long, came back with a vengeance." That year, when Geography and Geographers appeared, saw a series of events; the Iranian revolution, the election of the Margaret Thatcher, the emergence of Ronald Reagan on the national stage, the beginnings of marketization in China, plus confrontation in Afghanistan and dissent in Eastern Europe that would weaken the Soviet Union. Geographers were in a deep, decade-long dispute which pair of glasses-positivist, radical or humanistic- needed to be worn to comprehend societal shifts. Geography and Geographers intended to map the fractured terrain of this dispute
(Van Meeteren 2019a). By the mid-1980s, when Political Geography appeared, these shifts were changing the geopolitical and cultural landscape in ways that have come to define that of the early twentyfirst century. However, the stifling geography of Cold War geopolitics was still the world's primary metageographical canvas (Taylor 1994; see Berry 1973; Lewis and Wigen 1997 for metageography).

Political Geography explicitly aimed to unearth the emerging global unequal economic interdependencies overwritten by that dominant metageography. As noted by Peter in his response below, dependency theory and its connections to world-systems analysis were the key academic foundations (Frank 1969; Wallerstein 1979). The second edition of Political Geography completely reworked the chapter on geopolitics to nullify the existing separation of 'great power' competition from 'north-south' politics. The third edition ushered in some notable changes that provided the foundations for subsequent revisions. Notably, the topological model of the state was introduced, and world cities made an appearance; prefacing Peter's emerging research trajectory that would later find expression in the Globalization and World Cities Research Network. ${ }^{1}$ The fourth edition, the first to be co-authored, saw a change of tone. Less time was spent on the evolution of political geography's theoretical engagement with each of the chapter's topics; geopolitics, imperialism, the state, elections, etc. More time was spent on updating and adding contemporary examples. This change reflects the book's trajectory from its initial twin roles of textbook and an argument for a political geography based on world-systems analysis, to a focus on serving as a textbook, primarily, though one organized through the world-systems framework. The fourth edition contained the dramatic change of a new chapter. The chapter attempted the difficult balance of engaging a shift in the discipline, broadly speaking to the interest in identity engendered by the cultural turn while retaining the world-systems framework to maintain a coherent theme in the book. The fifth, sixth, and seventh editions added textbook features suggested by the publisher such as 'boxes' for case studies, further reading, and pedagogical activities. Theoretically, world cities played an ever-increasing role throughout

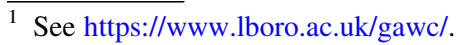


the book. Also, a conscious attempt was made to connect the structural framework of world-systems with the grounded approach of feminist geopolitics.

Front-covers of first and current editions of both books featured highly stylized cartography. Then and now, Political Geography's cover invoked the working and scales of a world-system, though the cog-like interactions of apparent territories ${ }^{2}$ in 1985 has become an abstract outline of the whole world in 2017. The front-cover of the first edition of Geography and Geographers was notable for the recognizable lattice of hexagons; a map associated with Walter Christaller's 1930s work on Central Places, the 1966 English translation of which informed ideas about spatial science that featured inside the covers. Within each hexagon was an image of a man; it would not be until the sixth edition (2004), the first to be co-authored, that feminist geography received a chapter. The hexagons and men appeared on the second (1983) and third (1987) editions too. The map on the front-cover of the seventh edition of Geography and Geographers is based on a photograph of the mosaic below the Monument to the Discoveries in Belém, Lisbon; a site that one of the co-authors of the seventh edition has elsewhere placed in postcolonial perspective (Power and Sidaway 2005). All of these covers were designed by the publishers rather than proposed by the authors (Fig. 1).

Both Geography and Geographers and Political Geography started out as contributions of their time and place and addressed clear lacunae in the discipline at their time of publication. The prefaces to the seventh edition of both books reflect on their foundations and subsequent evolution. Thus, Political Geography (Flint and Taylor 2018, pp. xi-xii) categorizes its various editions as:

1985 Foundation text, in which a particular theoretical perspective was brought to bear on the subject matter of political geography.

1989 Consolidation text, in which new ideas were

fleshed out to make for a more comprehensive

\footnotetext{
${ }^{2}$ Peter Taylor disliked the cover, as he recalled during the panel: "Never since that first edition came out, I have allowed a publisher to design a cover. The whole thing about worldsystems analysis, when people critique it, is that it provides a very mechanical view of the world, everything slots together, and it does not have any nuance. I obviously disagreed with that, but then they put cover on the book....with cogs on it.".
}

treatment of political geography (notably in terms of geopolitics and nationalism).

1993 Post-Cold War text, in which arguments had to be developed that took account of the traumatic 'geopolitical transition' anticipated by the 1989 (written in 1988) text.

1999 Globalization [the first to be jointlyauthored] text, in some sense returning to the original theoretical perspective, emphasized the 'global' when it was much less fashionable than it is today.

2007 Empire and War on Terrorism text, in which the processes of globalization were discussed in relation to the violent practices of terrorism and counter-terrorism.

\section{Empire, globalization and climate change} text, in which we see global political change being driven by three related processes: the role of cities in economic and political networks, the problems facing territorially based notions of democratic politics and citizenship, and the ongoing spectre of war.

2018 Corporatization of politics, challenges to globalization and the increasingly influential role of China text....

Similarly conscious of the evolution of the book, the preface to the seventh edition of Geography and Geographers (Johnston and Sidaway 2016, pp. xvixvii) engages reviews of prior editions and sketches alternative ways to map disciplinary history, noting how these offer different ways of 'recovering and imposing coherence on human geography's collective memory ${ }^{3}$ adding that:

\footnotetext{
3 These words, from the preface to Geography and Geographers seventh edition, are in turn a quotation from a commentary by Livingstone (2007) when Geography and Geographers featured as a 'classic in human geography' in Progress in Human Geography. In his own landmark account the The Geographical Tradition: Episodes in the History of a Contested Enterprise, Livingstone (1992, p. 45) had noted how the publication of Geography and Geographers in 1979 was part of what, for a then comparatively thin field of the history of the discipline, was: "opening the door to a greater critical spirit, to a desire to connect the subject with wider currents of intellectual moment, and to a concern to locate human geography's coordinates in a broader scholarly landscape.”.
} 

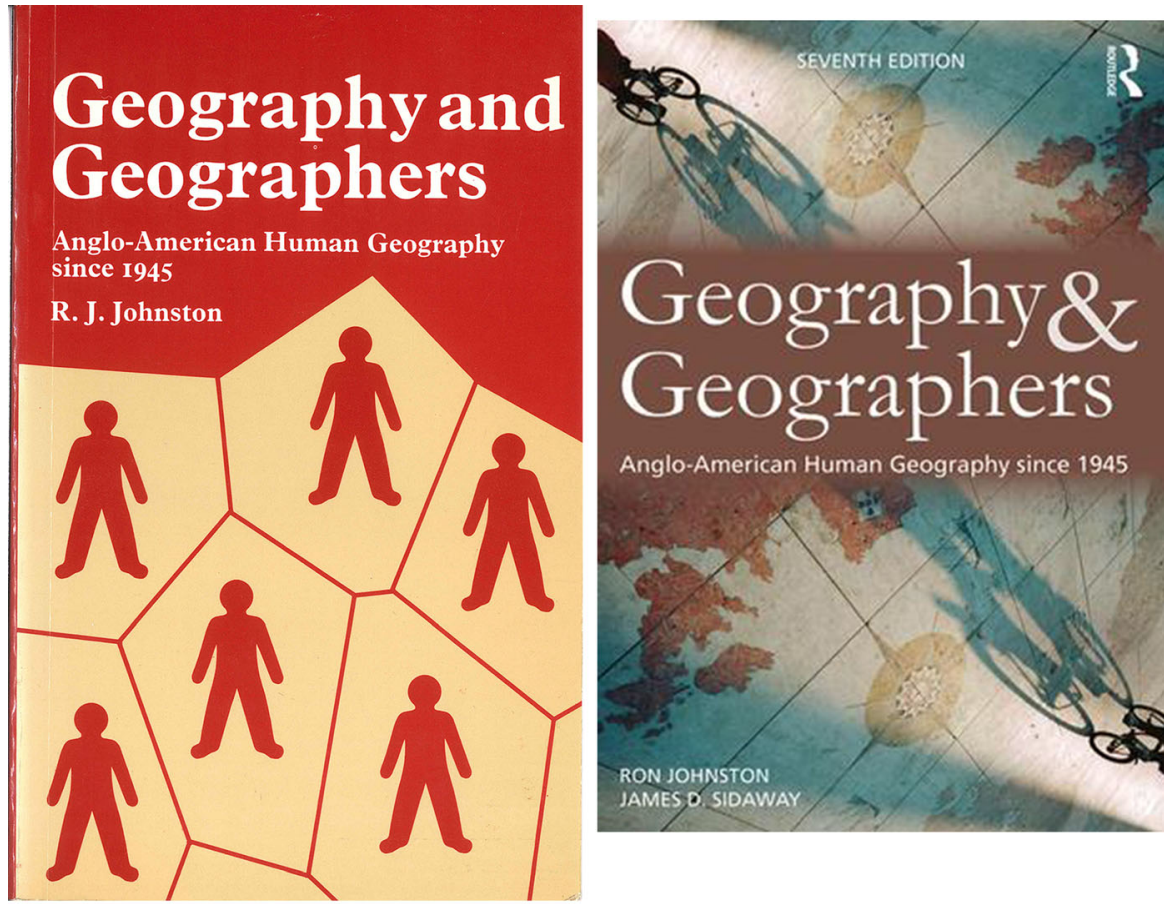

Anglo-American Human Geography since 1945
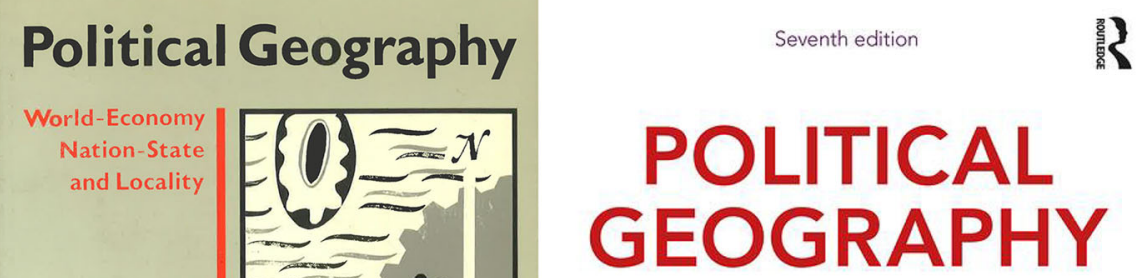

WORLD-ECONOMY, NATION-STATE AND LOCALITY

Peter J. Taylor
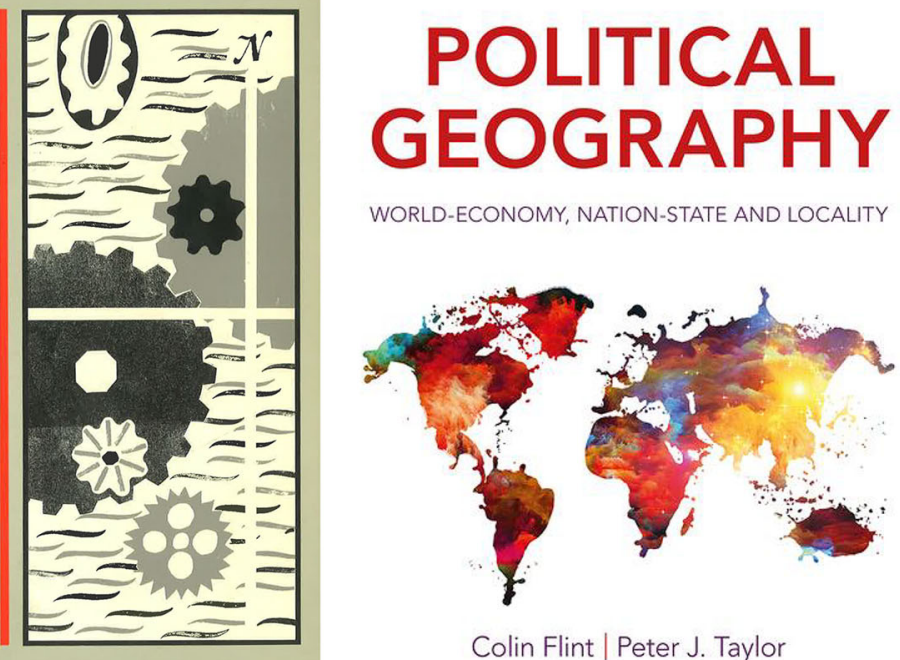

Colin Flint | Peter J. Taylor

Fig. 1 The front covers of the first and seventh editions of Geography and Geographers $(1979,2016)$ and Political Geography (1985, 2018)

The task of recovering and imposing that coherence has increased exponentially over the thirty-seven years since the appearance of the first edition, reflecting not just the expansions in human geographical scholarship and the ever- broadening canvass of geographical research, but also a growing volume of biographical and autobiographical works, providing new insights to specific events in disciplinary history and much changed (and still-changing) economic, 
political and institutional contexts in which those practices were situated.

Geography and Geographers has grown significantly through its seven editions, something Political Geography is only guilty of to a lesser extent. The first edition was 232 pages. The seventh contains 520, considerably larger, pages, bearing a smaller font. It runs to over 300,000 words. Throughout all editions however, the narrative history is sandwiched in between an opening chapter that examines the nature of an academic discipline and debates about how and why it changes and a final chapter that reviews and reevaluates those debates. As we noted above, feminist geography gained a separate chapter from the sixth edition. That sixth edition was also the first with a chapter on 'postmodernism, poststructuralism, postcolonialism'. The attempt to negotiate these in a single chapter was criticized by Philo (2009). The consequences of that compression in terms of the marginalization of black geography and geographers has been noted in subsequent engagements with the seventh edition (Boyle et al. 2017) and crops again up in the commentaries that follow.

At this point, we want to make a first invitation to readers to turn to the critiques and Ron Johnston's and Peter Taylor's responses before returning to this introduction. For in the next section, we will spoil the plot and summarize the contributions, use the position as respective textbook co-authors to fill in some remaining lacuna and play devil's advocate on some of the overarching issues that the dialogue raised.

\section{The commentaries}

The first editions of Geography and Geographers and Political Geography were, respectively, about tracing the rise of, challenges to and bringing into dialogue 'paradigms' in geography and infusing world-systems analysis into a somewhat moribund political geography. Both books were the codification of taught undergraduate courses designed to critique the mainstream of their day. However, as Michael Heffernan argues below, these books acquired a 'discipline-defining importance' as they matured: they became part of the canon they sought out to criticize. Being the flag-bearing publication of a subdiscipline brings responsibility, you have to become an enduring reference, books that radiate the 'optical consistency and semiotic homogeneity' that come with being the go to resource-or the 'obligatory passage point' (Latour 1990 as elaborated by Barnes 2002). In achieving such influence, Geography and Geographers and Political Geography somehow bucked the trend of the frequently short shelf life of geography textbooks (Sidaway and Hall 2017), in part because, as we have noted, there were few competing titles when the first editions of both textbooks appeared. Being canonical means that you acquire a responsibility of 'comprehensiveness'. This responsibility might guarantee the kinds of sales that ensure continued support from commercial publishers, but it also means the book has to keep up with multiple twists and turns of the discipline. This responsibility necessitated in the cases of these books' expansion of authorship into a new scholarly generation. Many of the critiques levelled at both works are about how the books, despite efforts to the contrary, fall short in the responsibility of comprehensiveness.

Accommodating new viewpoints can lead to, as Virginie Mamadouh notes, either diluting the punchy argument of the original (Political Geography) or the steady march to textbook obesity (Geography and Geographers), in the latter case fundamentally changing the function of the book from subject introduction to reference work (Van Meeteren 2019a). Yet, despite the efforts at including new viewpoints, Sharon Cheong, Katharine Hall, Michael Heffernan and Fiona McConnell all make strong cases about key omissions that could only further dilute or gain more weight if the omissions were to be patched. Moreover, it is salient that it is particularly the additions to later editions, such as engagement with feminist geography and postcolonialism, that are the source of contention.

Simultaneously, the contributions of Fiona McConnell, Lucas Melgaço and Virginie Mamadouh show how the themes that got snowed-under in Political Geography because of all the additions could actually be productive in engendering new dialogue. The polarized contemporary political climate that Katharine Hall mentions in her contribution might look more like the 1980s Cold War era that spawned the first edition than the context of some of the later editions. In other words, it seems that patches to the textbook in order to make it ready for new times are not as adhesive as might have been hoped, begging the question whether a 'back to basics' approach is vindicated. 


\section{The responses}

Both Ron Johnston's and Peter Taylor's responses share a sobering analysis that in the current state of academic knowledge production the authoritative textbook, that perhaps was an impossible aspiration to begin with, is now even more beleaguered. The first edition of Geography and Geographers concluded that 'human geography will continue "branching towards anarchy" (Johnston 1979, p. 189). The second edition carefully added that anarchy signified free association and voluntary cooperation and was 'not a synonym for chaos', before noting that:

There is no normal science, no consensus over a disciplinary matrix, no agreement over the right exemplars. Human geography is shifting conglomerate of small communities, with which many individuals are only weakly linked. (Johnston 1983 , p. 220)

Today, human geography's heterogeneous elements mean that surveying the field as a whole, or speaking across different silos, is even more difficult. There seems to be agreement across the commentaries and responses that the apparent order that these textbooks might have imposed on their objects of analysis has become less credible and that we currently are surrounded by fragmented remains, collated in silos that tend to be quite self-referential (Johnston 2005). The centre did not hold, and we can wonder whether to what extent there still exists something of a singular geographical mainstream especially, as Lucas Melgaço reminds us, when we fully acknowledge the prominence of distinct national/linguistic communities of geographical scholarship such as the Brazilian scene (Ferretti 2019). A consequence of such development is that the original plot of Geography and Geographers, the change mechanism of mainstreams that are consequently challenged by critics, who seek and may subsequently engender a wide turn or paradigm shift, is long eclipsed, replaced by a far more complex pattern.

So what kind of alternatives to the turning paradigms can we imagine to narrate the discipline? As Fiona McConnell wonders, how you can bring the margins centre stage in a geographical textbook, especially if the desired end-result is a coherent whole ready for undergraduate teaching? One promising outcome from the debate is a re-engagement with a more multilingual approach to geographical praxis (Ferretti 2019; Hassink et al. 2019) where a textbook embraces being various and incorrigibly plural (Barnes 2019). There might be value in rediscovering the distinctive merits once theorized in Dutch-language political geography that became backgrounded by the dominance of Political Geography as Virginie Mamadouh recalls. Moreover, as Lucas Melgaço suggests and Peter Taylor acknowledges, Political Geography would probably be a better book if it would make the translation with Brazilian world-systems type theorizing. Here we agree with Oswin (2020) that we are in dire need of texts that that bridge siloed scholarship in such a way that we can teach about the set of geographically-articulated problems around uneven development, environmental collapse, and contests over the boundaries of personal and collective identity and freedom, and national populisms that engulf our daily worlds. The key is what the criteria is for inclusion in such a paradigm, and in the spirit of engaged pluralism and being various this can only be achieved by Sisyphean labour (Keighren, 2016; Van Meeteren 2019b) where we are continuously disassembling and reassembling disciplines. In such a spirit our textbooks are not cast as timeless, but as vulnerable and provincialized standpoints, though nevertheless useful sites of engagement (Sidaway and Hall 2017; Van Meeteren and Sidaway 2020).

Of course, it would be unreasonable to assume that two geographers who are great-grandfathers and well over retirement-eligible age will formulate that textbook. Taylor and Johnston have devoted significant parts of their respective careers in developing and curating a narrative about subfields of geographical scholarship to guide teaching and students. It is now up to others to improve on their efforts. The challenge is significant, how to build a body of geographical scholarship that is able to provide a sustained period of explanation satisfying the denizens of academia and resonates beyond the fuzzy boundaries of subdisciplines? Many of the issues and omissions raised in the panelists' essays need to find a place in that body of scholarship, but the challenger has to include cutting the Gordian knots of brevity and coherence. To assist in that challenge, Political Geography and Geography and Geographers are inter-generational ${ }^{4}$ gifts, and we

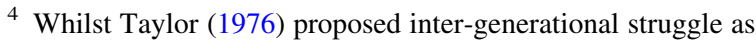
an interpretation of disciplinary change and Geography and Geographers has paid close attention to academic-career cycles from its first edition, arguably the trajectory of both books came to embody inter-generational collaboration.
} 
hope that this set of commentaries and the autobiographical embedding of the books allows that gift to be accepted (Van Meeteren 2019c). The books provide templates on how a textbook can be ordered and a decades-spanning documentation in the form of critiques, answers and reviews on how a better job might be done. New generations reject the calling at their own peril. Geography and Geographers and Political Geography remain, to help us guide through current troubled times, and we-and our studentsneed all the help in that endeavour we can get.

\section{References}

Barnes, T. J. (2002). Performing economic geography: Two men, two books, and a cast of thousands. Environment and Planning A, 34(3), 487-512.

Barnes, T. J. (2019). The importance of 'being various': A commentary on 'Moving beyond Anglo-American economic geography'. International Journal of Urban Sciences, 23(2), 170-176.

Berry, B. J. (1973). A paradigm for modern geography. In R. J. Chorley (Ed.), Directions in geography (pp. 3-22). London: Methuen.

Boyle, M., England, K., Farish, M., Beaten, G., Gilmartin, M., De Vivo, M. S., et al. (2017). Geography and geographers: Anglo-American human geography since 1945, 7th edition. AAG Review of Books, 5(1), 48-61.

Carson, R. (1962). Silent spring. Boston, MA: Houghton Mifflin.

Caryl, C. (2013). Strange rebels: 1979 and the birth of the 21st century. New York, NY: Basic Books.

Ferguson, N., Maier, C. S., Manela, E., \& Sargent, D. J. (Eds.). (1970s). The shock of the global: The 1970s in perspective. Cambridge, MA: Harvard University Press.

Ferretti, F. (2019). History and philosophy of geography I: Decolonising the discipline, diversifying archives and historicising radicalism. Progress in Human Geography. https://doi.org/10.1177/0309132519893442.

Flint, C., \& Taylor, P. J. (2018). Political geography: World-economy, nation-state, and locality (7th ed.). Abingdon: Routledge.

Frank, A. G. (1969). Latin America: Underdevelopment or revolution. New York: Monthly Review Press.

Hassink, R., Gong, H., \& Marques, P. (2019). Moving beyond Anglo-American economic geography. International Journal of Urban Sciences, 23(2), 149-169.

Hilton, M., Moores, C., \& Sutcliffe-Brathwaite, F. (1980s). New Times revisited: Britain in the 1980s. Contemporary British History, 31(2), 145-165.

Johnston, R. J. (1979). Geography and geographers: Angloamerican human geography since 1945. London: Edward Arnold.

Johnston, R. J. (1983). Geography and geographers: AngloAmerican human geography since 1945 (2nd ed.). London: Edward Arnold.
Johnston, R. J. (2005). Geography-coming apart at the seams? In N. Castree, A. Rogers, \& D. J. Sherman (Eds.), Questioning geography: Fundamental debates (pp. 9-25). Malden: Blackwell.

Johnston, R., \& Sidaway, J. D. (2016). Geography and geographers: Anglo-American human geography since 1945 (7th ed.). London: Routledge.

Keighren, I. M. (2016). History and philosophy of geography I. Progress in Human Geography, 41(5), 638-647.

Keighren, I. M. (2020). History and philosophy of geography III: The haunted, the reviled, and the plural. Progress in Human Geography, 44(1), 160-167.

Latour, B. (1990). Drawing things together. In M. Lynch \& S. Woolgar (Eds.), Representation in scientific practice (pp. 19-68). Cambridge: Cambridge University Press.

Lee, R. E. (2011). The modern world-system. Its structures, its geoculture, its crisis and transformation. In D. PalumboLiu \& B. Robbins (Eds.), Immanuel Wallerstein and the problem of the world: System, scale, culture. Durham, NC: Duke University Press.

Leitner, H., \& Sheppard, E. S. (2016). Provincializing critical urban theory: Extending the ecosystem of possibilities. International Journal of Urban and Regional Research, 40(1), 228-235.

Lewis, M. W., \& Wigen, K. E. (1997). The myth of continents: A critique of metageography. Berkeley CA: University of California Press.

Livingstone, D. N. (1992). The geographical tradition: Episodes in the history of a contested episode. Oxford: Blackwell.

Livingstone, D. N. (2007). Johnston, RJ. 1979: Geography and geographers: Anglo-American human geography since 1945. London: Edward Arnold. Commentary 1. Progress in Human Geography, 31, 43-45.

Oswin, N. (2020). An other geography. Dialogues in Human Geography, 10(1), 9-18.

Philo, C. (2009). Cultural turn. In R. Kitchin \& N. Thrift (Eds.), International encyclopaedia of human geography (pp. 442-450). Amsterdam: Elsevier.

Power, M., \& Sidaway, J. D. (2005). Deconstructing twinned towers: Lisbon's Expo '98 and the occluded geographies of discovery. Social and Cultural Geography, 6(6), 865-883.

Sidaway, J. D., \& Hall, T. (2017). Geography textbooks, pedagogy and disciplinary traditions. Area, 50(1), 34-42.

Slobodian, Q. (2018). Globalists: The end of empire and the birth of neoliberalism. Cambridge, MA: Harvard University Press.

Taylor, P. J. (1976). An interpretation of the quantification debate in British geography. Transactions of the Institute of British Geographers NS, 1, 129-142.

Taylor, P. J. (1994). From heartland to hegemony: Changing the world in political geography. Geoforum, 25(4), 403-411.

Van Meeteren, M. (2019a). Book review: Geography and geographers. Progress in Human Geography, 43(5), 959-960.

Van Meeteren, M. (2019b). On geography's skewed transnationalization, anglophone hegemony, and qualified optimism toward an engaged pluralist future; a reply to Hassink, Gong and Marques. International Journal of Urban Sciences, 23(2), 181-190. 
Van Meeteren, M. (2019c). The pedagogy of autobiography in the history of geographic thought. Norsk Geografisk Tidsskrift-Norwegian Journal of Geography, 73(4), 6-11.

Van Meeteren, M., \& Sidaway, J. D. (2020). History of geography. In A. Kobayashi (Ed.), International encyclopaedia of human geography (2nd ed., pp. 37-44). Boston, MA: Elsevier.

Villaume, P., Mariager, R., \& Porsdam, H. (Eds.). (2006). The 'Long 1970s': human rights, East-West détente and transnational relations. Abingdon and New York: Routledge.
Wallerstein, I. (1979). The capitalist world-economy. Cambridge: Cambridge University Press.

Watkins, S. (2020). Britain's decade of crisis. New Left Review, 121, 5-19.

Publisher's Note Springer Nature remains neutral with regard to jurisdictional claims in published maps and institutional affiliations. 